\title{
High Affinity cGMP-Specific 3',5'-Cyclic Phosphodiesterase 9A
}

National Cancer Institute

\section{Source}

National Cancer Institute. High Affinity CGMP-Specific 3',5'-Cyclic Phosphodiesterase 9A. NCI Thesaurus. Code C125491.

High affinity cGMP-specific 3',5'-cyclic phosphodiesterase 9A (593 aa, $68 \mathrm{kDa}$ ) is encoded by the human PDE9A gene. This protein plays a role in the conversion of cyclic nucleotide monophosphates to non-cyclic monophosphates. 